\title{
Artificial Night Lighting Reduces Firefly (Coleoptera: Lampyridae) Occurrence in Sorocaba, Brazil
}

\author{
Oskar Hagen1, Raphael Machado Santos1, Marcelo Nivert Schlindwein², \\ Vadim Ravara Viviani ${ }^{1,3^{*}}$ \\ ${ }^{1}$ Laboratório de Bioquímica e Biotecnologia de Sistemas Bioluminescentes, Universidade Federal de São Carlos, \\ Sorocaba, Brazil \\ ${ }^{2}$ Núcleo de Comportamento Animal e Manejo da Fauna Nativa, Laboratório de Ecologia, Universidade Federal \\ de São Carlos, Sorocaba, Brazil \\ ${ }^{3}$ Graduate School of Biotechnology and Environmental Monitoring, Universidade Federal de São Carlos, \\ Sorocaba, Brazil \\ Email: ${ }^{*}$ viviani@ufscar.br
}

Received 14 January 2015; accepted 28 January 2015; published 29 January 2015

Copyright (C) 2015 by authors and Scientific Research Publishing Inc.

This work is licensed under the Creative Commons Attribution International License (CC BY).

http://creativecommons.org/licenses/by/4.0/

(c) (i) Open Access

\begin{abstract}
Artificial night lighting is gaining attention as a new type of pollution; however, studies of its impacts are scarce. Fireflies provide good models to investigate its effects on nocturnal wildlife, since they depend on their bioluminescence for reproduction. This study investigated the impact of artificial illumination on firefly activity at the new campus of the Federal University of São Carlos (Sorocaba, Brazil). The flashing activity of different firefly species, especially Photinus sp1 (82\% of all occurrences), was investigated during 3 years, before and after the installation of multi metal vapor spotlights. Quantitative and qualitative analysis, performed in transects at different distances from the artificial light sources, showed significant negative effects on Photinus sp1 occurrence. This study proposes fireflies as potential flagship species and bioindicators for artificial night lighting and for the first time quantifies its effects, providing subsidies for future conservationist legislations regarding photopollution.
\end{abstract}

\section{Keywords}

Photopollution, Fireflies, Bioindicators, Flagship Species, Photinus

\footnotetext{
${ }^{*}$ Corresponding author.
} 


\section{Introduction}

Artificial night lighting has increased globally during the last decades [1], but conversely still receives little attention when compared to other kinds of pollutions [2]-[5]. Although plants and animals, i.e. birds, sea turtles, invertebrates and even humans are negatively affected by artificial light [2] [6], its effects have been for long neglected and detailed studies of its impacts are few [7]-[9].

Insects are adapted to natural light regimes and thus are sensitive to light in terms of periodicity [10]-[12], polarization [13]-[16], intensity, source and wavelength [16]-[20]. Among them, nocturnal insects have a highly sensitive visual system [21] and some display superposition compound eyes that are 100 - 1000 times more sensitive than that of apposition eyes (typical of diurnal insects) of the same size [17]. Thus, nocturnal insects can perform during night the same visual tasks as diurnal ones with comparable precision and accuracy [22] [23]. These activities include recognizing and reacting to conspecifics and predators, foraging [11] and navigating using stars [24] [25], moon [15] [26] and even learned visual landmarks [27]-[30]. Therefore, considering their adaptation to night lighting natural regimes, nocturnal insects are prone to be more sensitive to photopollution, being attracted, repelled, disoriented or blinded by artificial night lighting [9]. These and other interferences can subsequently alter behavior, dormancy, migration, activity levels (e.g. pollination, nectaring and bioluminescence), reproductive success, predator-prey balance and survivorship [9] [10] [31] [32], consequently scaling up to alterations on community compositions and beyond (e.g. ecosystem services, balance and stability) [32].

Among the few existing studies of the impacts of photopollution on insects, moths and other Lepidoptera are the most common focus organisms [33]-[36]. Due to photopollution, moths, which are key consumers, prey and pollinators, are suspected to experience declines in diversity and abundance [33] [34]. However, further studies are needed to achieve conclusive evidences. The attraction of Lepidoptera and Coleoptera to artificial light is known [36] for causing behavior and life cycle changes, increased exposure to predators, like birds [37] and bats [38] [39], or even direct mortality [9] [35]. Nevertheless, Van Langevelde and colleagues [34] indicated that larger wavelengths reduced the negative effects of photopollution on moth populations. Similar results were found when lights with shorter wavelengths (the ones emitting UV, high pressure mercury vapor, sodium-xenon and sodium vapor lamps, respectively) attracted more insects in abundance and diversity [31] [40]. Those findings agree with the visual ecology sensitivity to UV $(30-400 \mathrm{~nm})$ of nocturnal insects [17] [39] [41] and suggest that low pressure sodium lamps $(580-600 \mathrm{~nm})$ will have less impacts on insects than other lamps [20]. However, the scenario is much more complicated, since nocturnal insects discriminate spectral composition for different purposes and therefore have different sensibilities to light [17] [42].

Among nocturnal insects, fireflies are especially vulnerable to artificial night lighting since they depend on their bioluminescence for reproduction [2]; whereas click beetles and railroad worms use it additionally for defensive purposes [43] [44]. In fireflies, bioluminescence communication evolved to species-specific mating communication systems [44] [45] drawing a complex photoecology scenario. These beetles are active mainly after sunset and during the first hours of the night, since the visualization of the bioluminescent flashes is fundamental for their reproduction [43] [44] [46]-[50]. The beginning of their flashing activity has been shown to be modulated by environmental light intensity [48]. These facts support the hypothesis that firefly populations are negatively and strongly affected by artificial night lighting.

Bioindicators should be sensitive to environmental changes [51]. Fireflies, besides their sensitivity, can be easily spotted at night making them good candidates for environmental artificial night lighting bioindicators. Additionally, fireflies are charismatic (a rare characteristic among insects), making them potential flagship species regarding photopollution. Recent study [52] supports this idea given the strong participation of locals on a conservation project. Moreover, they found correlations between high levels of luminance and the absence of the firefly Luciola italica L. [52]. Nevertheless, more detailed quantitative studies are until now missing.

Brazil hosts the largest diversity of luminescent beetles in the world [53]. The southeastern is the most populated, developed and consequently artificially illuminated region and is undergoing continuous expansion. However, the effect of urban sprawl and artificial night lighting on the environment and on fireflies diversity is just starting to be investigated [7] [54]. Consequently, there is an urgent need for studies analyzing the impacts of artificial night lighting on the environment with the aim of providing subsidies for the creation of effective conservationist policies [2] [7]. This study was conducted at the new campus of the Federal University of São Carlos, Brazil (hereafter UFSCar) built in 2008. It is located at a rural area of Sorocaba municipality which is undergoing urban sprawl, providing a good site to investigate the effects of artificial night lighting on firefly occurrence. 


\section{Material and Methods}

From 2006 to 2007, we catalogued the biodiversity of luminescent beetles in the study area before the installation of the main artificial light sources. From November 2008 to December 2010, we measured the effects of artificial light on firefly diversity and populations, totalizing 82 days of field observations.

\subsection{Study Area}

The UFSCar campus is located in the periphery of Sorocaba municipality in a rural area (Figure 1) (23⒊'53"S and $47^{\circ} 31^{\prime} 28^{\prime \prime} \mathrm{W}, 666 \mathrm{~m}$ above sea level), southeastern Brazil. The region is characterized by hot and humid tropical climate, with an average annual temperature of $21^{\circ} \mathrm{C}$, and monthly averages over $20^{\circ} \mathrm{C}$ between October and April. In the summer and rainy season, the average monthly temperature is $22^{\circ} \mathrm{C}$ with $200 \mathrm{~mm}$ of rainfall. The winter and dry season is from April to October, with droughts from June to September with temperatures below $18^{\circ} \mathrm{C}$ and $30 \mathrm{~mm}$ of precipitation. Local vegetation consists of small fragments $(<11$ ha) of remnant Atlantic rain forest surrounded by implanted pastures consisting mostly of the introduced grass Brachiaria sp., thus characterizing a typically degraded area. The area was used as pasture since the beginning of the 19th century with no history of artificial illumination nor use of pesticides.

\subsection{Artificial Light Sources}

The light sources in the area were: a) sodium vapor lamps along the pavements near the university buildings; b) indoor fluorescent lamps; c) a red light on a water tank ( $\approx 300 \mathrm{~m}$ from the studied area); d) "skyglow" [2] from the Sorocaba City at Northeast (usually a yellowish-orange glare, depending on atmospheric conditions) and neighborhoods on the west (white) and east (yellow to red); e) four spotlights from a sport court with three multi metal vapor lamps each (model HQI-T $400 \mathrm{~W}$ ) that was the main source of light near the transects and became operational in August 2009.

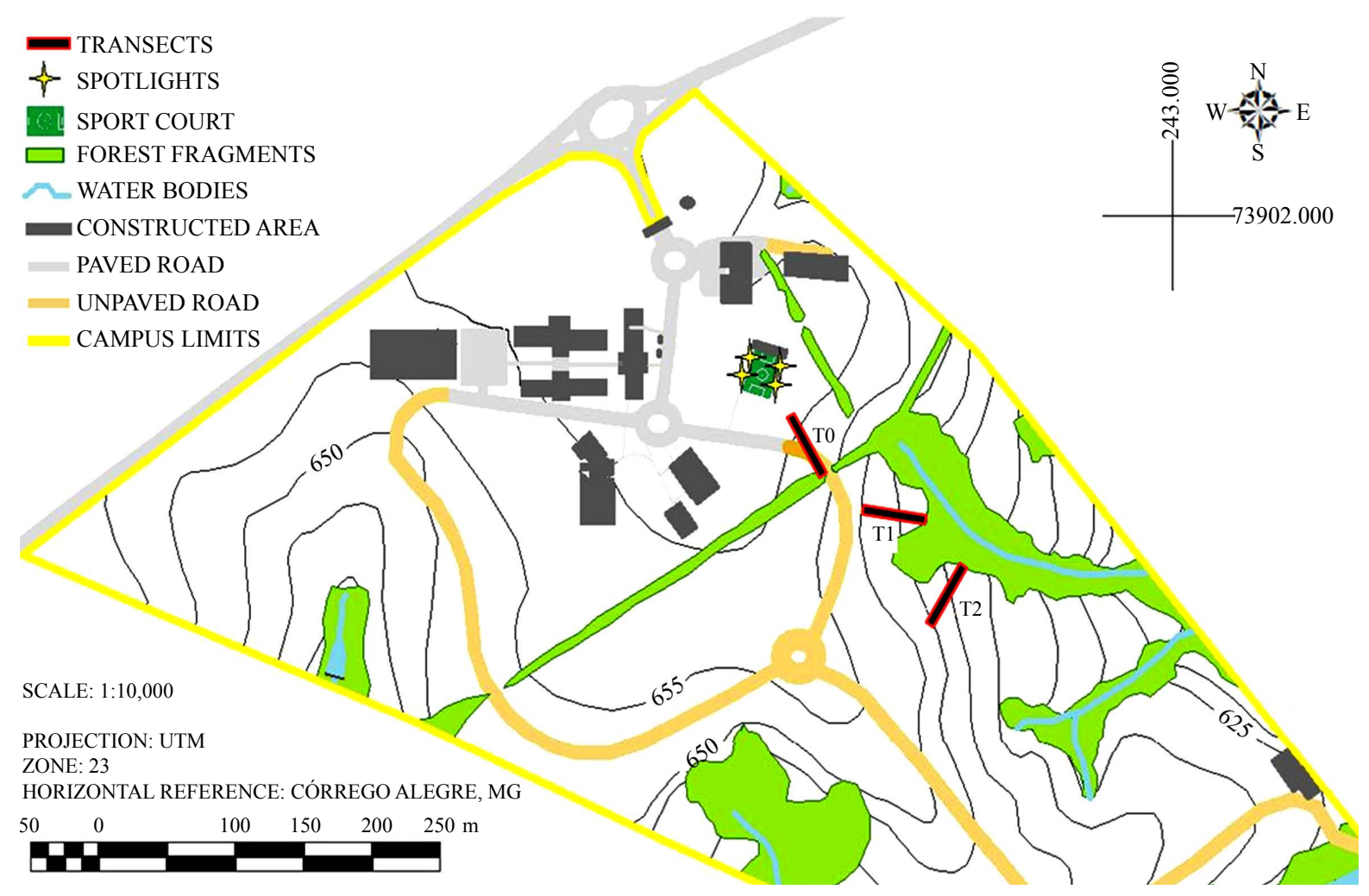

Figure 1. Study area in 2010, showing the position of the three transects (T0, T1 and T2), spotlights, constructions, vegetation and water bodies. 


\subsection{Transects and Measurements}

Three transects of $50 \times 2$ meters were determined and named T0, T1 and T2 (Figure 1). All the transects ended on fragments of semi-deciduous forest in early regeneration state and were walked in $1 \mathrm{~min}$. The positions where chosen for their relationship to the main artificial light source e): $\approx 60 \mathrm{~m} \mathrm{~T} 0, \approx 150 \mathrm{~m} \mathrm{~T} 1$ and $\approx 280 \mathrm{~m} \mathrm{~T} 2$. Transects $\mathrm{T} 0$ and $\mathrm{T} 1$ were directly illuminated by the spotlights of the sport court (Figure 1).

Twice a week transects were randomly visited every 10 minutes. Measurements were initiated after the time of sunset and ended after $120 \mathrm{~min} .363$ transects were scanned when the spotlights were turned on, and 346 when off. The state of the spotlights was totally random and dictated by the usage of the sport court.

For each transect the following parameters were recorded: light intensity; time; quantity and quality of coverage of the sky measured in eighths; temperature; relative humidity; wind; moon phase. The number of flashing individuals (here referred as occurrences) was quantified by counting the meetings during the transect scanning. The recurrence or several flashes from the same individual during the transect course was counted as one occurrence. Fireflies were identified in field by their flashing pattern according to the authors experience on previous works [53] [54]. In case of doubt, the fireflies were collected with hand nets and identified by direct comparison with the Coleoptera collection at UFSCar. Environmental light intensities were measured in lux (wavelength peak at $530 \mathrm{~nm}$; bandwidth $=470-650 \mathrm{~nm}$ ) using a Skye SKL-310 photometer, by positioning the sensor at $90^{\circ}$ to the ground before each transect was monitored. For direct light intensity, the sensor was positioned toward the light source.

\subsection{Data Analysis}

The software R version 3.0 was used for the statistical analysis and the generation of all graphs. A KruskalWallis test was performed between six groups which were created by aggregating all transects and spotlight conditions. After that, a Wilcoxon test for each transect was carried out in regard of treatment spotlights on and off.

\section{Results}

\subsection{Biodiversity}

The following species were found among the 400 occurrences: (Lampyridae) Photinus sp1, Aspisoma physonotum, Aspisoma lineatum, Amydetes fucata and Pyrogaster moestus; (Elateridae) Pyrearinus micatus and Pyrophorus divergens (Table 1).

Lampyridae was the most represented family with $98 \%$ of the occurrences whereas Elateridae was represented with only $2 \%$. The occurrence of Photinus sp1 was much higher in the investigated sites than all the other species, limiting our statistical analysis for this species (Table 1 and Figure 2). Figure 2 shows the mean monthly occurrence of Lampyridae species.

Table 1. Number and percentage of species for each transect and state of the spotlights.

\begin{tabular}{|c|c|c|c|c|c|c|c|c|}
\hline & \multicolumn{2}{|c|}{ Light on } & \multirow{2}{*}{$\frac{(30 \%)^{*}}{\text { T2 }}$} & \multicolumn{2}{|c|}{ Light off } & \multirow{2}{*}{$\begin{array}{c}(70 \%)^{*} \\
\text { T2 }\end{array}$} & \multirow{2}{*}{ Total } & \multirow{2}{*}{$\%$} \\
\hline & T0 & $\mathrm{T} 1$ & & T0 & $\mathrm{T} 1$ & & & \\
\hline \multicolumn{9}{|l|}{ Lampiridae } \\
\hline Photinus sp1 & 6 & 30 & 58 & 43 & 91 & 100 & 328 & $82.00 \%$ \\
\hline Aspisoma physonotum \& Aspisoma lineatum & 3 & 6 & 9 & 11 & 4 & 4 & 37 & $9.30 \%$ \\
\hline Amydetes fucata & 0 & 0 & 2 & 9 & 2 & 0 & 13 & $3.30 \%$ \\
\hline Pyrogaster moestus & 0 & 2 & 5 & 1 & 1 & 4 & 13 & $3.30 \%$ \\
\hline \multicolumn{9}{|l|}{ Elateridae } \\
\hline Pyrearinus micatus \& Pyrophorus divergens & 0 & 0 & 0 & 0 & 4 & 5 & 9 & $2.30 \%$ \\
\hline Total & 9 & 38 & 74 & 64 & 102 & 113 & 400 & $100 \%$ \\
\hline $\mathrm{n}^{\circ}$ of transects & 125 & 117 & 121 & 113 & 122 & 111 & 709 & \\
\hline
\end{tabular}

${ }^{*}$ Absolute percentage of occurrences for each spotlight state. 
Morphological and behavioral flash patterns observed in the field gave us confidence to identify the most occurring individuals above mentioned as the same morpho-species previously reported as Photinus sp1 [53] [54]. However, due to hindrances such as species descriptors older than one century, high local variation and lack of specialized taxonomists, Photinus spl could not be identified beyond genus. Nevertheless, priority was given to report a poorly explored but substantial threat to firefly populations, as we mean to underscore in this paper.

Photinus sp1 ( $\lambda \max =571 \mathrm{~nm}$, yellow light) [53], was active from $20-100$ minutes after sunset, with peak of activity at 50 minutes (see black mean plots in Figure 3). Flashing activity of the other fireflies was reported for Aspisoma physonotum and Aspisoma lineatum (20 - $100 \mathrm{~min})$, Amydetes fucata (30 - $80 \mathrm{~min})$, Pyrogaster moestus (30 - $70 \mathrm{~min})$, Pyrearinus micatus and Pyrophorus divergens (30 - $40 \mathrm{~min})$.
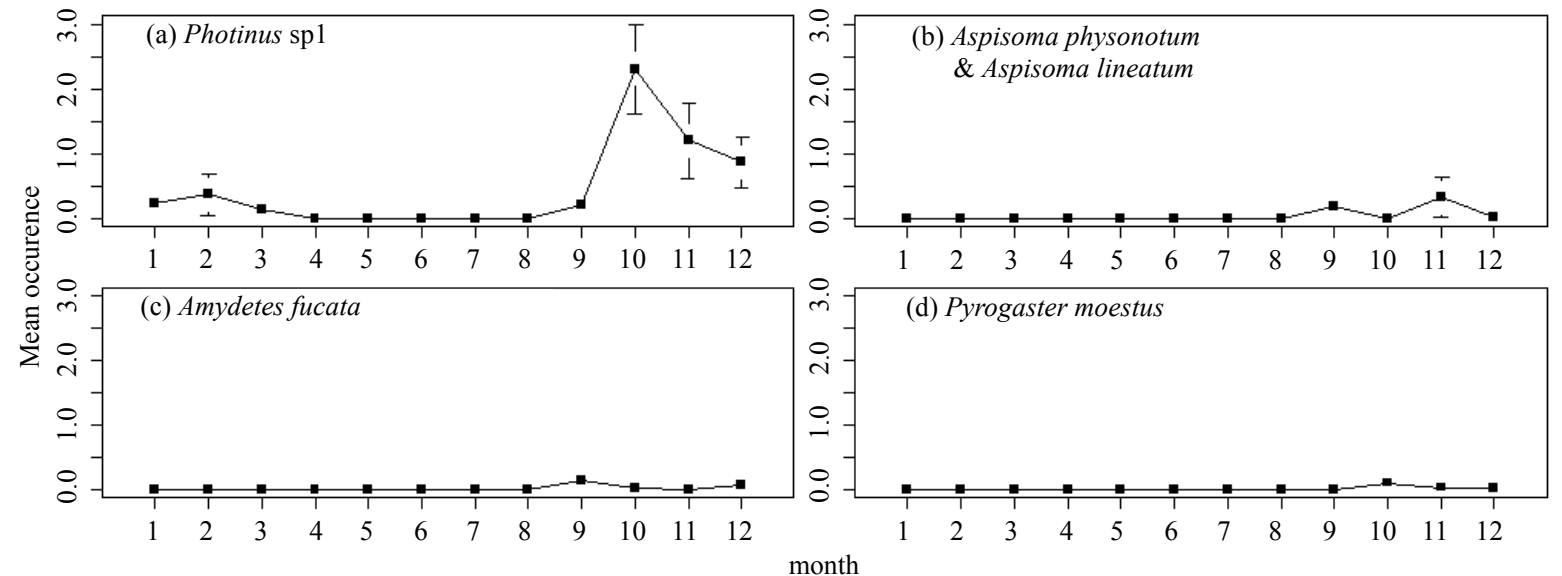

Figure 2. Monthly mean occurrences (confidence interval of 95\%) for Lampyridae firefly species: (a) Photinus sp1, the most abundant species; (b) Aspisoma physonotum and Aspisoma lineatum, plotted together; (c) Amydetes fucata; (d) Pyrogaster moestus.

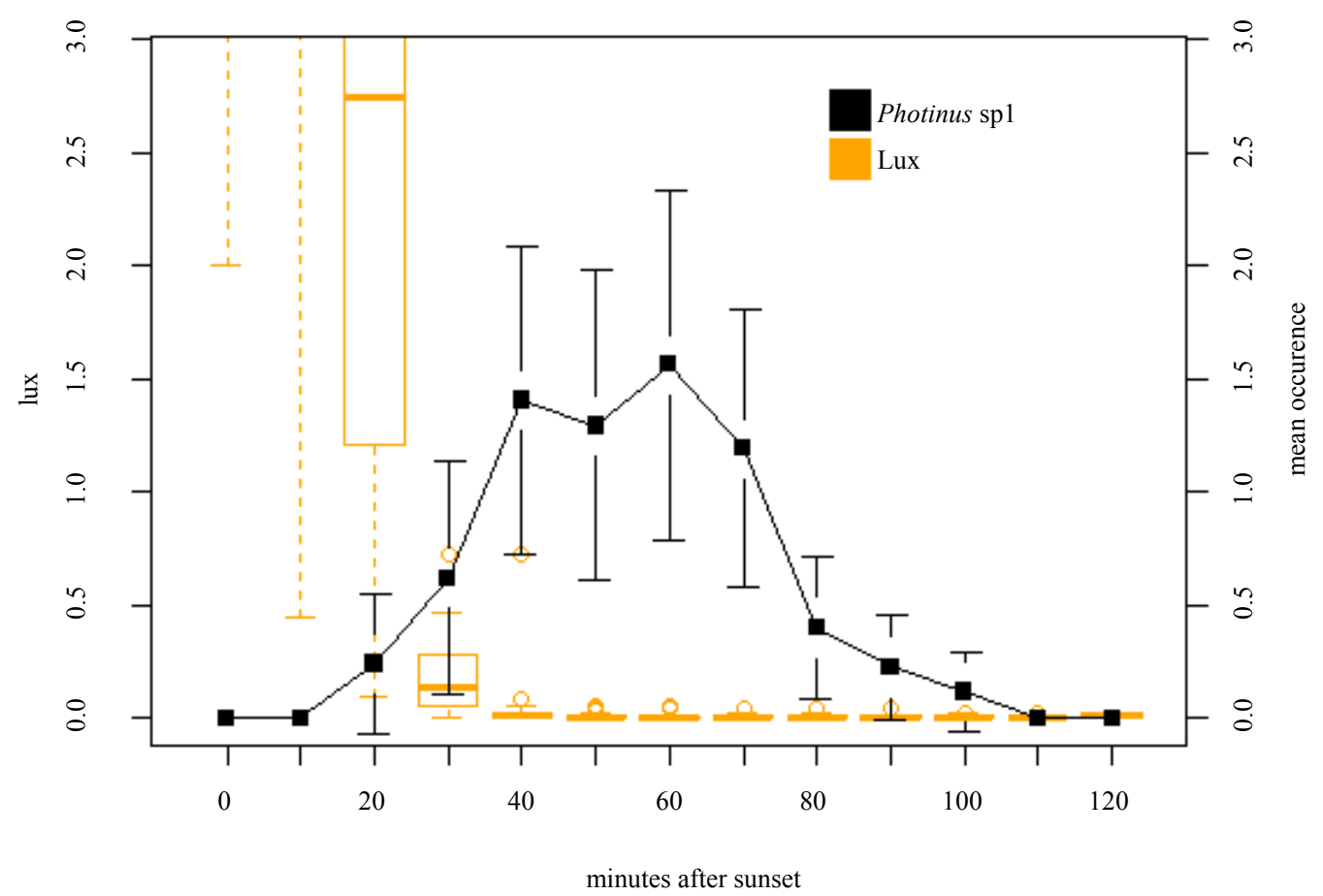

Figure 3. Relationship between the occurrence of Photinus sp1 (flashing activity, confidence interval of 95\%) and environmental artificial luminosity (measured in lux) over time (in minutes after the sunset). Yellow boxes enclose $50 \%$ and lines $95 \%$ of the environmental artificial luminosity, and the median is indicated by the horizontal bar. 


\subsection{Night Lighting Intensities and Firefly Occurrence}

The decay of natural environmental light stabilized around 40 - 50 minutes after the sunset (see yellow boxplots in Figure 3). At 40 minutes after sunset the direct light intensity of the Spotlights at T0 was $4.45 \pm 0.001$ lux, T1 $1.5 \pm 0.001$ lux and T2 $0.05 \pm 0.001$ lux ( $\mathrm{n}=10$ measurements each). Comparatively, at full moon nights (without cloud cover and spotlights), the mean environmental light intensities was $0.0438 \pm 0.044$ lux ( $n=51$ transects). The highest observed intensity of artificial environmental light during flashing activity was 0.234 lux for Photinus sp1. For Pyrogaster moestus, Aspisoma lineatum and Aspisoma physonotum the highest observed intensities were between $0.001-0.05$ lux in this site. There was a highly significant difference (Kuskal-Wallis $\mathrm{P}=$ $4.97 \times 10^{-7}$ ) between artificial groups of combined transects and spot states (Figure 4). The difference on the occurrence of Photinus sp1 on each transects (T0, T1 and T2) with different treatments, spots on and off, and the respective Wilcoxon test, is shown in Figure 4.

\section{Discussion}

The time of flashing activity of fireflies is determined by natural environmental light levels [50]. Therefore a nighttime with excessive environmental light may affect the time of activity as well as the detection of bioluminescence signals emitted by potential sexual partners [50]. Furthermore, the activity of fireflies may also be influenced by the chromaticity of bioluminescence emission against the environmental photic background [50]. During the twilight in vegetated fields, the diffused ambient light spectrum is predominantly green [55], generating a green photic background which may interfere with the detection of bioluminescent signal of fireflies with similar bioluminescence spectrum. On the other hand, in full darkness, green bioluminescence will be reflected by foliage, turning the signal more easily detectable by the partner [55]. Conversely, individuals with yellow bioluminescence may have greater likelihood to detect intra-specific signals during twilight, due to the better contrast between yellow bioluminescence and the green photic background [49] [56].

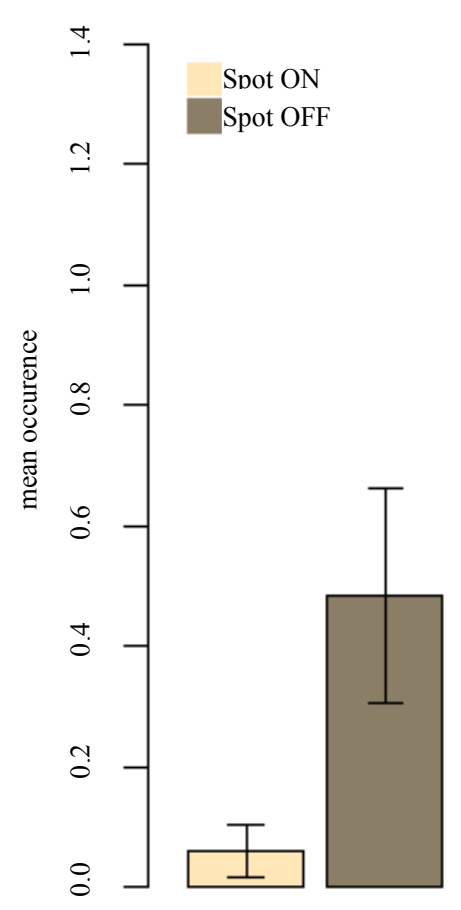

T0

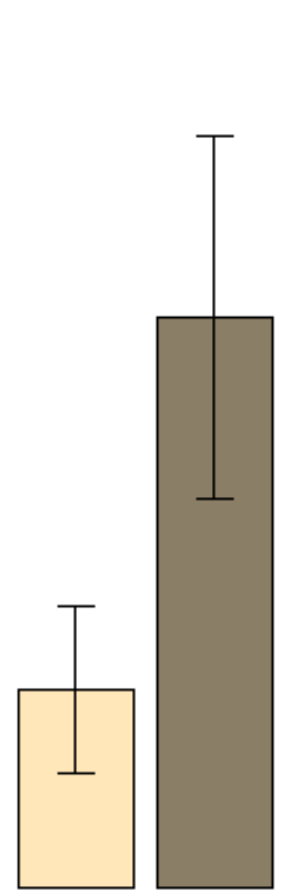

$\mathrm{T} 1$

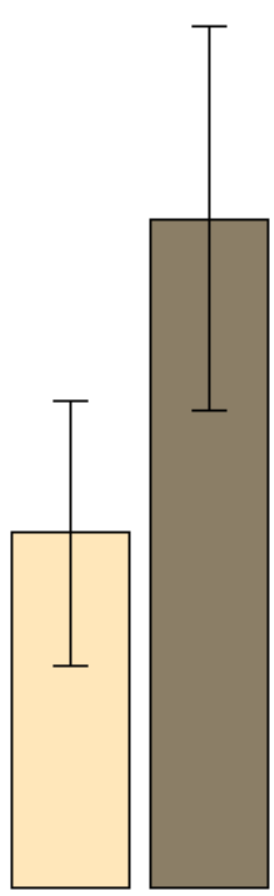

T2

Figure 4. Effect of direct illumination on Photinus sp1 occurrence. Mean occurrence of Photinus sp1 (confidence interval of 95\%) at T0, T1 and T2 (difference of means $=87.4 \%, 65.2 \%$ and $46.9 \%$ respectively) with the light on $(n=363$ transects) and off ( $n=346$ transects). A Wilcoxon test for mean occurrence on each transect among lights on and off had for T0, T1 and $\mathrm{T} 2 \mathrm{P}=0.00015, \mathrm{P}=0.04042$ and $\mathrm{P}=0.01882$ respectively. 
The flashing activity of Photinus sp1 starts from 20 minutes and lasts until 90 minutes after sunset (Figure 3) with peak at 50 minutes after the sunset, when it is already dark and the environmental light is stabilized (Figure 3). Although displaying yellow bioluminescence [53], which would put Photinus sp1 into the class of twilight active fireflies according to the North American category [50], Photinus sp1 is active mostly in the dark. This could be explained by the fact that in the Southeastern region of Brazil a clear relationship between firefly activity after sunset and bioluminescence color is not found, probably due to the shorter duration of twilight at lower latitudes when compared to higher latitudes of temperate zones [57]. We suspect the high relative abundance of Photinus sp 1 (Table 1) is related with a chronic photopollution exposure of the area, which possibly created a favorable environment for yellow glowing species.

The negative influence of artificial illumination on Photinus sp1 occurrence (Figure 4) can be explained by the strong and fast change in environmental night lighting scenario in the course of few years. Considering an evolutionary time scale of adaptation, the spotlights provided a direct illumination that was up to 100 -fold stronger than the strongest natural light source (average lighting of full moon nights without cloud cover). Moreover the spotlights emit a polychromatic light, with bands peaking at different wavelengths that match firefly bioluminescence spectra, differentially affecting distinct species.

The main finding of this study is the influence of artificial nightlight (multi metal vapor spotlights direct illumination of 4.45 lux in $\mathrm{T} 0 \approx 60 \mathrm{~m}$ ) on Photinus sp1 occurrence based on its flashing activity. Despite the Wilcoxon test being significant only for T0 (Figure 4), the percentage of the mean difference for the areas farther from the spotlight were inversely proportional to the light source distance, suggesting that the average number of occurrences is considerably reduced in transects closer to the spotlights (from $47 \%$ up to $87 \%$ of occurrence suppression).

Although Photinus sp1 could not be identified yet, we can safely assure that it consists of a single species based on morphological characters, flash pattern and ecological aspects. Further studies are necessary to better understand the complete ecological impact of photopollution on firefly diversity and populations. First, the spectral characterization of artificially illuminated environments could reveal the impact of different kinds of polychromatic light sources on firefly photoecology (i.e. based on its relationship with bioluminescence spectra of persistent and locally extinct species). Second, sampling control areas historically distant from artificial light may help to better assess the effect of artificial light pollution.

\section{Conclusion}

Our findings illustrate the negative effect of artificial light on the activity of a Photinus species, thus providing a first quantitative evidence of artificial night lighting effects on firefly occurrence. We also propose fireflies as bioindicators and flagship species among nocturnal insects. Besides contributing to the promotion of the awareness regarding photopollution, this and complementary studies can hopefully provide subsidies to support stakeholders on creation of laws concerning artificial night lighting.

\section{References}

[1] Cinzano, P., Falchi, F. and Elvidge, C.D. (2001) The First World Atlas of the Artificial Night Sky Brightness. Monthly Notices of the Royal Astronomical Society, 328, 689-707. http://dx.doi.org/10.1046/j.1365-8711.2001.04882.x

[2] Rich, C. and Longcore, T. (2006) Ecological Consequences of Artificial Night Lighting. Island Press, Washington DC.

[3] Gallaway, T., Olsen, R.N. and Mitchell, D.M. (2010) The Economics of Global Light Pollution. Ecological Economics, 69, 658-665. http://dx.doi.org/10.1016/j.ecolecon.2009.10.003

[4] Gallaway, T. (2010) On Light Pollution, Passive Pleasures, and the Instrumental Value of Beauty. Journal of Economic Issues, 44, 71-88. http://dx.doi.org/10.2753/Jei0021-3624440104

[5] Hölker, F., et al. (2010) The Dark Side of Light: A Transdisciplinary Research Agenda for Light Pollution Policy. Ecology and Society, 15, 1-11.

[6] Navara, K.J. and Nelson, R.J. (2007) The Dark Side of Light at Night: Physiological, Epidemiological, and Ecological Consequences. Journal of Pineal Research, 43, 215-224. http://dx.doi.org/10.1111/j.1600-079X.2007.00473.x

[7] Barghini, A. (2010) Antes que os vaga-lumes desapareçam ou influencia da iluminação artificial sobre o ambiente. Annablume, São Paulo.

[8] Longcore, T. and Rich, C. (2004) Ecological Light Pollution. Frontiers in Ecology and the Environment, 2, 191-198. http://dx.doi.org/10.1890/1540-9295(2004)002[0191:ELP]2.0.CO;2 
[9] Bruce-White, C. and Shardlow, M. (2011) A Review of the Impact of Artificial Light on Invertebrates. Buglife-The Invertebrate Conservation Trust, Peterborough.

[10] Saunders, D.S. (2012) Insect Photoperiodism: Seeing the Light. Physiological Entomology, 37, 207-218. http://dx.doi.org/10.1111/j.1365-3032.2012.00837.x

[11] Kerfoot, W.B. (1967) The Lunar Periodicity of Sphecodogastra texana, a Nocturnal Bee (Hymenoptera: Halictidae). Animal Behaviour, 15, 479-486. http://dx.doi.org/10.1016/0003-3472(67)90047-4

[12] Saunders, D.S. (2009) Circadian Rhythms and the Evolution of Photoperiodic Timing in Insects. Physiological Entomology, 34, 301-308. http://dx.doi.org/10.1111/j.1365-3032.2009.00699.x

[13] Horvath, G., Kriska, G., Malik, P. and Robertson, B. (2009) Polarized Light Pollution: A New Kind of Ecological Photopollution. Frontiers in Ecology and the Environment, 7, 317-325. http://dx.doi.org/10.1890/080129

[14] Dacke, M., Nilsson, D.E., Scholtz, C.H., Byrne, M. and Warrant, E.J. (2003) Insect Orientation to Polarized Moonlight. Nature, 424, 33. http://dx.doi.org/10.1038/424033a

[15] Dacke, M., Byrne, M.J., Scholtz, C.H. and Warrant, E.J. (2004) Lunar Orientation in a Beetle. Proceedings of the Royal Society of London. Series B: Biological Sciences, 271, 361-365. http://dx.doi.org/10.1098/rspb.2003.2594

[16] Herzmann, D. and Labhart, T. (1989) Spectral Sensitivity and Absolute Threshold of Polarization Vision in Crickets: A Behavioral Study. Journal of Comparative Physiology A, 165, 315-319. http://dx.doi.org/10.1007/BF00619350

[17] Warrant, E.J. and Dacke, M. (2011) Vision and Visual Navigation in Nocturnal Insects. Annual Review of Entomology, 56, 239-254. http://dx.doi.org/10.1146/annurev-ento-120709-144852

[18] Kelber, A., Balkenius, A. and Warrant, E.J. (2002) Scotopic Colour Vision in Nocturnal Hawkmoths. Nature, 419, 922-925. http://dx.doi.org/10.1038/nature01065

[19] Hamdorf, K. (1979) The Physiology of Invertebrate Visual Pigments. In: Autrum, H., Ed., Comparative Physiology and Evolution of Vision in Invertebrates, Springer Heidelberg, Berlin, 145-224.

[20] Lamphar, H.A.S. and Kocifaj, M. (2013) Light Pollution in Ultraviolet and Visible Spectrum: Effect on Different Visual Perceptions. PloS ONE, 8, e56563. http://dx.doi.org/10.1371/journal.pone.0056563

[21] Exner, S. (1891) Die Physiologie der facettirten Augen von Krebsen und Insecten. Eine Studie, Leipzig.

[22] Warrant, E.J. (2008) Nocturnal Vision. The Senses: A Comprehensive Reference, 2, 53-86.

[23] Warrant, E.J. (1999) Seeing Better at Night: Life Style, Eye Design and the Optimum Strategy of Spatial and Temporal Summation. Vision Research, 39, 1611-1630. http://dx.doi.org/10.1016/S0042-6989(98)00262-4

[24] Gould, J.L. (2013) Animal Navigation: A Galaxy of Cues. Current Biology, 23, R149-R150. http://dx.doi.org/10.1016/j.cub.2013.01.003

[25] Dacke, M., Baird, E., Byrne, M., Scholtz, C.H. and Warrant, E.J. (2013) Dung Beetles Use the Milky Way for Orientation. Current Biology, 23, 298-300. http://dx.doi.org/10.1016/j.cub.2012.12.034

[26] Sotthibandhu, S. and Baker, R.R. (1979) Celestial Orientation by the Large Yellow Underwing Moth, Noctua pronuba L. Animal Behaviour, 27, 786-800. http://dx.doi.org/10.1016/0003-3472(79)90015-0

[27] Warrant, E.J. (2008) Seeing in the Dark: Vision and Visual Behaviour in Nocturnal Bees and Wasps. Journal of Experimental Biology, 211, 1737-1746. http://dx.doi.org/10.1242/jeb.015396

[28] Somanathan, H., Borges, R.M., Warrant, E.J. and Kelber, A. (2008) Nocturnal Bees Learn Landmark Colours in Starlight. Current Biology, 18, 996-997. http://dx.doi.org/10.1016/j.cub.2008.08.023

[29] Ugolini, A. and Chiussi, R. (1996) Astronomical Orientation and Learning in the Earwig Labidura riparia. Behavioural Processes, 36, 151-161. http://dx.doi.org/10.1016/0376-6357(95)00025-9

[30] Klotz, J.H. and Reid, B.L. (1993) Nocturnal Orientation in the Black Carpenter antCamponotus pennsylvanicus (DeGeer) (Hymenoptera: Formicidae). Insectes Sociaux, 40, 95-106. http://dx.doi.org/10.1007/BF01338835

[31] Eisenbeis, G. (2006) Artificial Night Lighting and Insects: Attraction of Insects to Streetlamps in a Rural Setting in Germany. Ecological Consequences of Artificial Night Lighting, 2, 191-198.

[32] Davies, T.W., Bennie, J. and Gaston, K.J. (2012) Street Lighting Changes the Composition of Invertebrate Communities. Biology Letters, 8, 764-767. http://dx.doi.org/10.1098/rsbl.2012.0216

[33] Fox, R. (2013) The Decline of Moths in Great Britain: A Review of Possible Causes. Insect Conservation and Diversity, 6, 5-19. http://dx.doi.org/10.1111/j.1752-4598.2012.00186.x

[34] Van Langevelde, F., Ettema, J.A., Donners, M., WallisDeVries, M.F. and Groenendijk, D. (2011) Effect of Spectral Composition of Artificial Light on the Attraction of Moths. Biological Conservation, 144, 2274-2281. http://dx.doi.org/10.1016/j.biocon.2011.06.004

[35] Frank, K.D., Rich, C. and Longcore, T. (2005) Effects of Artificial Night Lighting on Moths. In: Longcore, T. and Rich, 
C., Eds., Ecological Consequences of Artificial Night Lighting, Island Press, Washington DC, 305-344.

[36] Young, M., Wells, L. and Leverton, R. (1997) The Natural History of Moths. T \& AD Poyser Ltd., London.

[37] Long, C.V., Flint, J.A. and Lepper, P.A. (2011) Insect Attraction to Wind Turbines: Does Colour Play a Role? European Journal of Wildlife Research, 57, 323-331. http://dx.doi.org/10.1007/s10344-010-0432-7

[38] Polak, T., Korine, C., Yair, S. and Holderied, M.W. (2011) Differential Effects of Artificial Lighting on Flight and Foraging Behaviour of Two Sympatric Bat Species in a Desert. Journal of Zoology, 285, 21-27.

[39] Briscoe, A.D. and Chittka, L. (2001) The Evolution of Color Vision in Insects. Annual Review of Entomology, 46, 471510. http://dx.doi.org/10.1146/annurev.ento.46.1.471

[40] Allema, A.B., Rossing, W.A.H., van der Werf, W., Heusinkveld, B.G., Bukovinszky, T., Steingröver, E., et al. (2012) Effect of Light Quality on Movement of Pterostichus melanarius (Coleoptera: Carabidae). Journal of Applied Entomology, 136, 793-800. http://dx.doi.org/10.1111/j.1439-0418.2012.01728.x

[41] Stavenga, D. (2002) Colour in the Eyes of Insects. Journal of Comparative Physiology A, 188, 337-348. http://dx.doi.org/10.1007/s00359-002-0307-9

[42] Duehl, A.J., Arbogast, R.T., Sheridan, A.B. and Teal, P.E. (2012) The Influence of Light on Small Hive Beetle (Aethina tumida) Behavior and Trap Capture. Apidologie, 43, 417-424. http://dx.doi.org/10.1007/s13592-011-0106-9

[43] Lloyd, J.E., Wing, S.R. and Hongtrakul, T. (1989) Ecology, Flashes, and Behavior of Congregating Thai Fireflies. Biotropica, 21, 373-376. http://dx.doi.org/10.2307/2388290

[44] Lloyd, J.E. (1966) Studies on the Flash Communication System in Photinus Fireflies. Museum of Zoology, University of Michigan, Ann Arbor.

[45] Lewis, S.M. and Cratsley, C.K. (2008) Flash Signal Evolution, Mate Choice, and Predation in Fireflies. Annual Review of Entomology, 53, 293-321. http://dx.doi.org/10.1146/annurev.ento.53.103106.093346

[46] Lall, A., Cronin, T.W., Carvalho, A.A., de Souza, J.M., Barros, M.P., Stevani, C.V., et al. (2010) Vision in Click Beetles (Coleoptera: Elateridae): Pigments and Spectral Correspondence between Visual Sensitivity and Species Bioluminescence Emission. Journal of Comparative Physiology A: Neuroethology, Sensory, Neural, and Behavioral Physiology, 196, 629-638. http://dx.doi.org/10.1007/s00359-010-0549-x

[47] Michaelidis, C.I., Demary, K.C. and Lewis, S.M. (2006) Male Courtship Signals and Female Signal Assessment in Photinus greeni Fireflies. Behavioral Ecology, 17, 329-335. http://dx.doi.org/10.1093/beheco/arj035

[48] Lloyd, J.E. (1983) Bioluminescence and Communication in Insects. Annual Review of Entomology, 28, 131-160. http://dx.doi.org/10.1146/annurev.en.28.010183.001023

[49] Lall, A.B., Lord, E.T. and Trouth, C.O. (1982) Vision in the Firefly Photuris lucicrescens (Coleoptera: Lampyridae): Spectral Sensitivity and Selective Adaptation in the Compound Eye. Journal of Comparative Physiology A: Neuroethology, Sensory, Neural, and Behavioral Physiology, 147, 195-200. http://dx.doi.org/10.1007/BF00609844

[50] Lall, A.B., Seliger, H.H., Biggley, W.H. and Lloyd, J.E. (1980) Ecology of Colors of Firefly Bioluminescence. Science, 210, 560-562. http://dx.doi.org/10.1126/science.210.4469.560

[51] McGeoch, M.A. (1998) The Selection, Testing and Application of Terrestrial Insects as Bioindicators. Biological Reviews, 73, 181-201.

[52] Picchi, M.S., Avolio, L., Azzani, L., Brombin, O. and Camerini, G. (2013) Fireflies and Land Use in an Urban Landscape: The Case of Luciola italica L. (Coleoptera: Lampyridae) in the City of Turin. Journal of Insect Conservation, 17, 1-9.

[53] Viviani, V.R. (2001) Fireflies (Coleoptera: Lampyridae) from Southeastern Brazil: Habitats, Life History, and Bioluminescence. Annals of the Entomological Society of America, 94, 129-145. http://dx.doi.org/10.1603/0013-8746(2001)094[0129:FCLFSB]2.0.CO;2

[54] Viviani, V.R., Rocha, M.Y. and Hagen, O. (2010) Bioluminescent Beetles (Coleoptera: Elateroidea: Lampyridae, Phengodidae, Elateridae) in the Municipalities of Campinas, Sorocaba-Votorantim and Rio Claro-Limeira (SP, Brazil): Biodiversity and Influence of Urban Sprawl. Biota Neotropica, 10, 103-116.

http://dx.doi.org/10.1590/S1676-06032010000200013

[55] Endler, J.A. (1993) The Color of Light in Forests and Its Implications. Ecological Monographs, 63, 2-27. http://dx.doi.org/10.2307/2937121

[56] Lall, A.B. and Lloyd, J.E. (1989) Spectral Sensitivity of the Compound Eyes in Two Day-Active Fireflies (Coleoptera: Lampyridae: Lucidota). Journal of Comparative Physiology A: Neuroethology, Sensory, Neural, and Behavioral Physiology, 166, 257-260. http://dx.doi.org/10.1007/BF00193470

[57] Viviani, V.R. and Bechara, E.J.H. (1995) Bioluminescence of Brazilian Fireflies (Coleoptera: Lampyridae): Spectral Distribution and $\mathrm{pH}$ Effect on Luciferase-Elicited Colors. Comparison with Elaterid and Phengodid Luciferases. Photochemistry and Photobiology, 62, 490-495. http://dx.doi.org/10.1111/j.1751-1097.1995.tb02373.x 
Scientific Research Publishing (SCIRP) is one of the largest Open Access journal publishers. It is currently publishing more than 200 open access, online, peer-reviewed journals covering a wide range of academic disciplines. SCIRP serves the worldwide academic communities and contributes to the progress and application of science with its publication.

Other selected journals from SCIRP are listed as below. Submit your manuscript to us via either submit@scirp.org or Online Submission Portal.
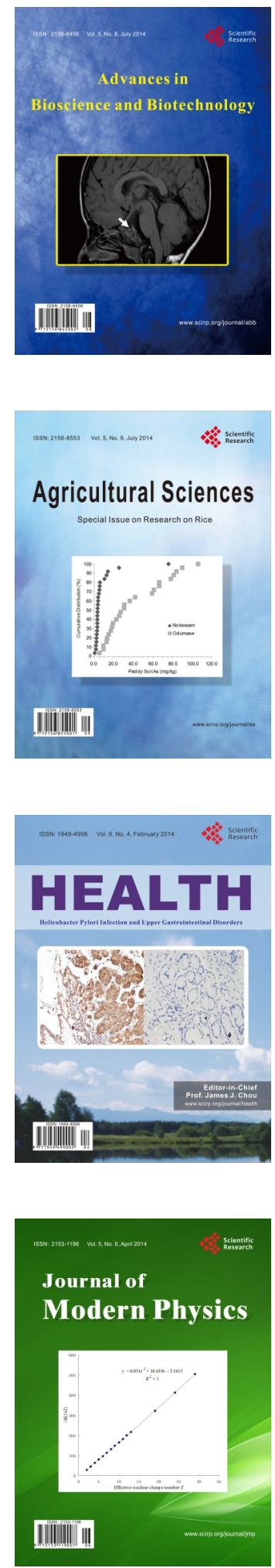
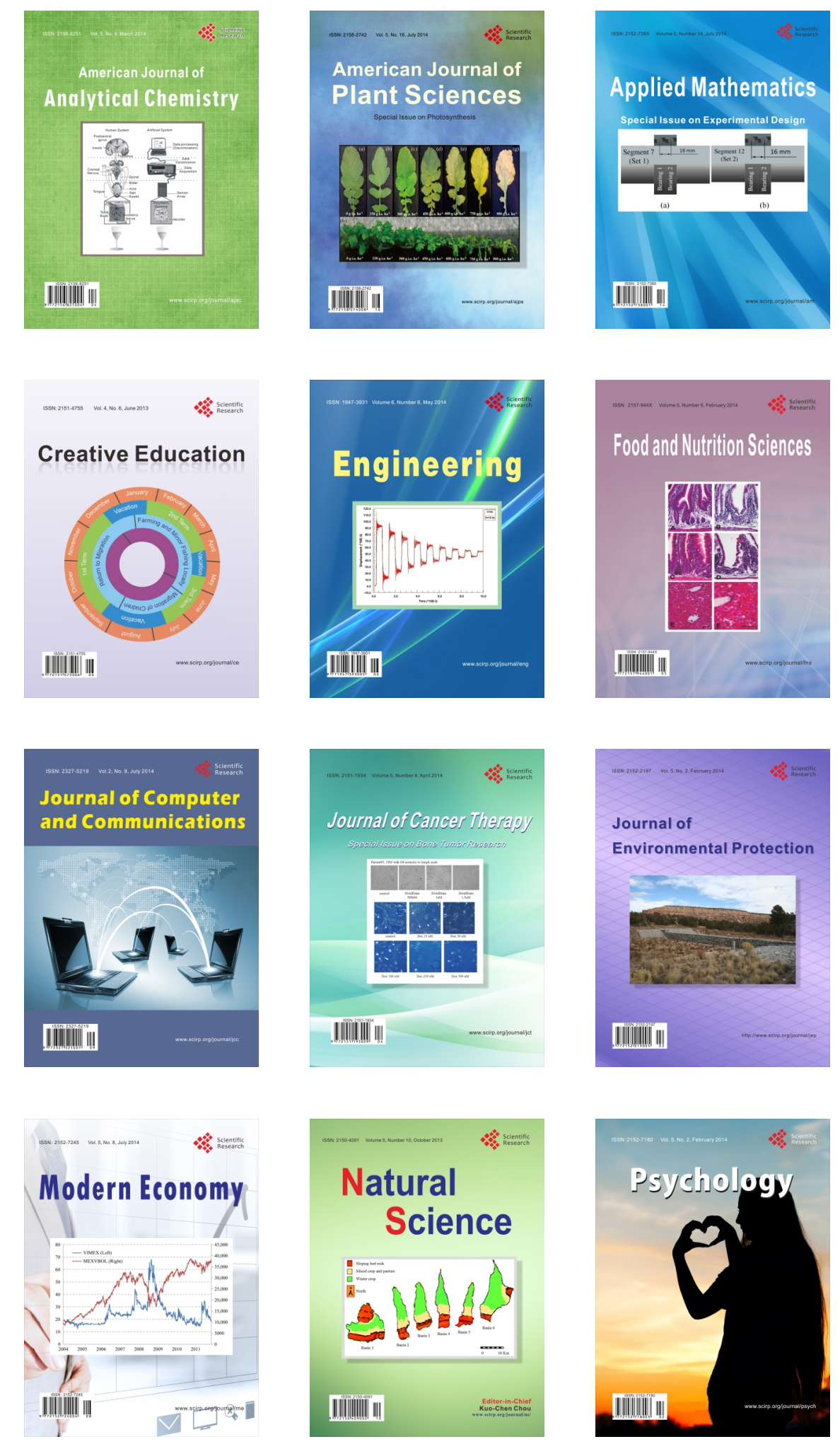